\title{
Toward a Muslim Ethics of Care: Leadership in American Islamic schools
}

Amaarah DeCuir

American University

\begin{abstract}
In this empirical study, I describe how Muslim women leading American Islamic schools enact a critical ethics of care framework in their leadership work. As previous critical studies indicate, this research moves beyond caring as an expression of emotion to the work of caring that transforms a community into one that can challenge inequities by building a climate of cultural affirmation. Through an analysis of qualitative interviews of such women, I advance a concept of Muslim ethics of care that communicates the caring work of school leaders rooted in establishing equity. The following four themes form the foundation of this conceptual framework: (a) caring to lead with equitable school practices; (b) caring as resistance to oppression, (c) caring through nurturing often described as "other mothering," (d) and caring as an Islamic obligation. This study places these leaders' voices within the broader context of a critical ethics of care framework, thereby demonstrating the role of faith-marginalized community leaders as social justice advocates.
\end{abstract}

\section{Introduction}

Ethics roots the teaching, learning, and leadership practices of a school organization (Smith, 2014). This a system of beliefs, values, and attitudes shapes the work priorities of educators by delineating right from wrong, fair from unjust, and urgent from nonessential. Scholars confirm that education leaders are responsible for establishing and sustaining a school's moral and ethical climate (Cherkowski, Walker, \& Kutsyuruba, 2015). Schools typically reflect multiple ethical expressions representing the diverse perspectives of their students, teachers, administrators, and community members, all of whom simultaneously influence the school's climate. Ethical leadership is considered a practice of working collaboratively with others to model interdependence and form the guiding principles that communicate excellence within a school (Dufresne \& 
McKenzie, 2009). This includes demonstrating respectful relationships and effective learning communities across stakeholder groups and being fully engaged in critical inquiry (Klenowski \& Ehrich, 2016).

Although education research describes and examines ethical leadership in various school contexts, the leadership work within American Islamic schools (hereinafter "schools") remains an underrepresented context in education scholarship. These schools represent a faith-based school network that advances Islamic beliefs, attitudes, and values as the overarching ethical frameworks of teaching, learning, and leadership practices. This article centers the voices of the women leading them to narrate how they conceptualize ethical leadership in their school contexts. The first section presents the existing literature on the intersections of social justice and ethical leadership, the second section positions the ethics of care framework as a lens for drawing meaning from their leadership work, and the third and final section describes the findings and discussion of the empirical study to advance a Muslim ethics of care framework.

\section{Literature Review}

Ethics of social justice leadership. Social justice work is rooted in the establishment of equitable life experiences, specifically education. Integrating the ethical work of school leaders and social justice advocacy reframes ethical leadership in the field of education as one that synthesizes personal ethics, professional values, and legal standards to advance democratic ideals of social justice (Tenuto \& Gardiner, 2018). Failure to integrate ethical leadership and social justice advocacy risks implementing ethical frameworks that replicate the structured inequities within schools by reflecting those values, beliefs, and attitudes from the larger society that do not challenge the status quo. As leaders identify unjust systems within their schools, their subsequent decision to replace them with equitable practices advances educational excellence for all (Dantley \& Tillman, 2006; Furman, 2012; Gardiner \& Tenuto, 2015). This creates an imperative among ethical, social justice leaders to persevere with leadership work that eliminates inequities and fosters cultural proficiency: "Therefore, justicespecifically social justice-is an essential connector for ethical leadership" (Gardiner \& Tenuto, 2015).

Ethics of care leadership. Starratt (1996, 2004, 2014) advanced a multidimensional framework to organize three related concepts of leadership ethics. This article focuses on the ethics of care because it is a central human emotion, empirical evidence links student achievement with caring, and our current societal norms suggest the existence of a crisis of caring associated with, and inconsistent, marginalized appreciation for, the essential work needed to evoke caring among school leaders (Smylie, Murphy, \& Seashore-Louis, 2016). Ethics of care is 
defined as the leadership work necessary for developing caring and respectful relationships with staff, students, and community members to construct a positive and welcoming climate that fosters a sense of belonging and meaning (Klenowski \& Ehrich, 2016). Each relationship is to be nurtured at the individual level, as well as on a case-by-case basis, to advance ethical leadership (Dufresne \& McKenzie, 2009). This is not to be perceived as a "warm and fuzzy" approach to ethical leadership, but rather as a moral imperative rooted in care, attention, and empathy (Noddings, 2012). An ethics of care centers the dignity and worth of all human beings (Starratt, 1996) and motivates leaders to care for the fate of others through their ethical leadership work (Gilligan, 1982).

Critical ethics of care. Applying critical theory to an ethics of care results in a framework that cultivates a strong sense of self and community to overcome those inequities that challenge the humanity of marginalized people and their communities. Going beyond the traditional White female ethics of care that simply stops at the act of caring, a critical ethics of care uses that act to transform a community (Sosa-Provencio, 2016), which causes it to be conceptualized as "political, transformative, and rooted in the collective uplift of those struggling to overcome these forces of oppression in their daily lives" (Sosa-Provencio, 2016, p. 306). Recognizing that the application of ethics is neither apolitical nor postracial, a critical ethics of care centers the social justice realities of communities of color through the following key elements (Sosa-Provencio, 2016):

- Validating the multiple identities and native ways of knowing of young people of color;

- Cultivating perseverance to challenge the historical and current sociopolitical inequities faced by young people and their families; and

- Developing the resilience to negotiate and ultimately thrive in the highly racialized and oppressive educational structures of schooling (pp. 303304).

Another articulation of critical ethics of care emanates from an African American lens integrating both womanism and Black feminist theory. It represents an African American community priority of social consciousness based on resistance to oppression, which encourages a school climate of caring that bolsters attention to social justice (Robinson \& Mazid, 2016). As African American women typically operate through the intersectionalities of race, gender, and social class, their leadership work under an ethics of care acknowledges their strong attachment to caring for marginalized and disadvantaged students due to their shared personal experiences and identification with oppression (Bass, 2012). I situate my work of Muslim women school leaders within this critical ethics of care. 
Praxis of Ethics of Care. School leaders who operate within an ethics of care sustain a complex set of actions and interactions that organize their daily work. Smylie, Murphy, and Seashore-Louis (2016) categorized the efforts leading to an ethics of care as aims, positive virtues and mindsets, and competencies. One core aim is to help students feel cared for, for this makes them willing to put in the necessary work to increase their academic achievement for fear of disappointing those who care about their future (Mitra, 2004). Those leaders who focus on expressing care for students win their trust and create spaces for them to be heard, which cause students to increase their interest in school and achievement (Bass, 2012). The embodiment of positive virtues and mindsets within an ethics of care enables leaders to be perceived as legitimate role models who make decisions for the best outcomes of the school community (Brown, Trevino, \& Harrison, 2005). In addition, students increase their capacity to care for others, and their expression of such caring influences the social relationships and climate across the school organization (Smylie, Murphy, \& Seashore-Louis, 2016).

Leading from an ethics of care requires one to demonstrate ethical callings for "social uplift," because it seeks to empower communities marginalized by social institutions (Sosa-Provencio, 2016). This is also referred to as "politicized mothering," for the work of caring extends to advocacy focused on removing the structured inequalities that block student achievement (Beauboeuf-Lafontant, 2005). Leading from an ethics of care prioritizes ongoing and systematic inquiries about student learning in order to identify school-based inequities that school leaders can address (Comber \& Kamler, 2009; Klenowski \& Ehrich, 2016). At times this work may involve professional risks, from implementing nontraditional or creative strategies to effectively educating marginalized students in the face of the school's unjust policies and practices (Bass, 2012).

Leadership within American Islamic Schools. American Islamic schools were founded to provide an environment for academic achievement in a religiously affirming space for students marginalized by their faith identity. From the early schools of the 1970s founded by African American members of the Nation of Islam to more contemporary schools founded primarily by immigrant communities, these schools provide a refuge from a larger society immersed in anti-Muslim sentiment (Rashid \& Muhammad, 1992; Esposito, 2011). Today's school communities, which include indigenous, immigrant, and convert populations, reflect the Muslim population's global diversity (Memon, 2017). Their leaders are responsible for establishing school climates that simultaneously challenge the larger society's socio-political inequities and fashion an American Muslim identity shared by people from around the world (DeCuir, 2016).

Reflecting the priorities of critical Black feminist leadership, the women leading these schools model social justice efforts to challenge the unjust 
expressions of anti-Muslim sentiment and create leadership practices rooted in the embodiment of justice and fairness (Khalil \& DeCuir, 2018). Their leadership work can also be examined by using the frameworks of a critical ethics of care to identify those beliefs, motivations, and practices of caring used as a conduit for transformative community change. The following qualitative study of this underrepresented school context is conceptualized through a critical ethics of care.

\section{Methodology}

Critical feminist scholarship is utilized in education research to make inequities explicit and identify social justice goals (Capper, 2015; Khalifa et al., 2016). Researchers can use this lens to conceptualize leadership as resistance against structures of oppression by culturally sustaining leadership that uplifts marginalized communities (Murtadha \& Watts, 2005). As a Muslim woman who led a school for over seven years, I center my examination of school leadership on an indigenous way of knowing cultural practices (Khalifa et al., 2016) that is facilitated by a shared religious identity. This enabled me to articulate the tacit knowledge associated with Islam, Muslim women, and Muslim women's experiences of leading such schools (Khalil \& DeCuir, 2018).

I conducted a secondary data analysis of thirteen participant interviews from a larger study of women leading schools. The participants included a national sample of heads of schools, principals, assistant principals, and one school board member drawn from indigenous Americans, immigrants from the Arab world and Southeast Asia, and second-generation immigrants from those two regions. The majority had six to ten years of leadership experience, although some were novices and others had fifteen or more years of experience. Because the national population of school leaders is relatively small and familiar - just over 250 schools - all participant data has been summarized to mask their identities.

Rather than simply describing their leadership work tasks, the participants and I constructed a shared understanding of the meaning of their work by making the implicit explicit in order to advance a complex representation of the roles and responsibilities of school leaders. This study considers the extent to which a critical ethics of care leadership framework can reflect the work priorities of the women leading these schools. In the subsequent sections, I use the participants' first-person voice accounts to describe how they utilize caring to achieve their leadership work.

\section{Findings}


The intersecting identities of woman, Muslim, and school leader come together to form a complex identity as a female leader of an American Islamic school in a manner that is distinct from the dominant representations of school leadership. These school leaders constantly navigate external pressures to confront systems of oppression that challenge their legitimacy, while also managing internal systems of cultural biases that question their femininity. Despite the pressures directed toward them individually, they utilize an ethic of care to communicate an affirmation of a community transformed through anti-Muslim sentiment in the larger society and rooted in the practices of their Islamic faith. In the following paragraphs, I outline four attributes of an ethics of care that they expressed while describing their roles and responsibilities: (a) caring to lead with equitable school practices; (b) caring as resistance to oppression; (c) caring through nurturing, often described as "other mothering"; and (d) caring as an Islamic obligation.

Caring to lead with equitable school practices. The women leading American Islamic schools reflected an ethic of caring by seeking to establish schools with equitable practices rooted in their religious convictions informed by the traditions of Prophet Muhammad, who exemplified fairness, equity, and antiracism. Many families choose to enroll their children despite their limited resources because they are actively pursuing an equitable learning experience in order to uplift their children's religious identity and confront anti-Muslim sentiments that restrict student access to success. Being fully aware of these motivations, these leaders demonstrate a strong ethic of care to ensure that the limited resources are distributed equitably through sound financial stewardship, sharing administrative roles, and increasing their own competencies to envision new pursuits of social justice outcomes.

Several leaders described accepting responsibilities beyond the traditional scope of a leadership role in order to build equitable school experiences for the students, faculty, and staff. Aim ${ }^{1}$ supervised students whose parents dropped them off too early. Although she understands that her school discouraged this practice, she cared about their safety from the moment they arrived.

Supervising the kids, making sure they are here, safe, is one of the biggest responsibilities that we have as an administrator here. Parents have trusted us, as in any school, that during the whole day while they're here, they're going to be safe, and they're going to be taken care of.

\footnotetext{
${ }^{1}$ All names are pseudonyms selected by the participants.
} 
Khadija B. understood that she would have to assume multiple tasks to institute equitable functions at her school: "This is really vague, but things happen in our building and we don't have back up like the public school systems...I'm probably doing the work of 10-15 people." Her sentiment is echoed by other participants, who shared that they administer first aid, create the food-service menu, drive the school bus, serve as a receptionist, and take over a classroom when its teacher is absent. These women recognize the comprehensive resources and systems embedded in public schools and demonstrate a strong ethic of caring, for they are motivated to produce equitable school systems in their under-sourced schools.

Many of the leaders reviewed their internal school functions to ensure that they were enacting equitable teaching and learning experiences for all of their students. One participant described petitioning her school board for additional funding to support children with special needs. Another one shared how she advised parents to seek testing in public schools for special needs identification so that they could obtain equitable school experiences outside of the Islamic school context. Jamilah mentioned that she confronts parents seeking special favors based on personal connections and family networks. She then makes these intentions explicit and challenges them as being inequitable and unjust approaches. Sumayyah challenged a board decision to publicly identify students whose families made late tuition payments on the grounds that this inequitable practice wrongfully communicated a student's socio-economic status. In each narrative, the women expressed care for students by working to establish equitable school experiences for all.

Finally, the leaders also demonstrated care in their work to organize equitable school environments for faculty, staff, and board members. Shanti invited the state association of independent schools to train members of her school's board to ensure that the highest level of leadership practices was rooted in fairness and justice. She also described implementing a system of classroom observations based on mutual collaboration and pedagogical support. Instead of confronting typical observational practices based on fear and catching a person off guard, she wanted to observe teachers regularly and produce "an environment in our school where there's no intimidation." S.P. established strong faculty departments to encourage teacher leadership by caring for their sense of empowerment to instill real change in the school's teaching and learning processes. Jamilah supported this by implementing a collaborative leadership system so that teachers could make shared decisions with the administrators.

So it makes very strong teachers. So if anything happens with administration, I would be very comfortable with having the teachers run the school for a short term...Some administrators are intimidated by strong teachers and staff. But for me, it makes my 
life easier if they know their job and they are taking care of business.

Because many of these leaders started out as faculty or staff, they recognize unjust leadership practices that replicate inequities. These women described caring for the school by working diligently to instill equitable practices, even if doing so involved more administrative work or petitioning for additional resources. Their caring did not stop at expressing their emotions, for their sense of caring sought to transform operations to that they would embody the existence of fair and just principles.

Caring as resistance to oppression. A critical ethics of care includes the work needed to resist all forms of oppression. Some of the participants described confronting oppression both inside and outside the school when patriarchal forces challenge their work as school leaders. Jamilah remembered how, when she was asked to speak to a non-Muslim audience, her mere presence challenged their outdated, patriarchal notions of meek and oppressed Muslim women.

As a Muslim woman who is in a leadership position and who is well-spoken, I am often the one who is asked to address nonMuslim audiences to break stereotypes and fight Islamophobia. I am never asked to speak about Islam; instead, the topic given to me is always "women in Islam"...As a Muslim female who is very clearly identifiable as such, people tend to listen more because part of the stereotype is that we are ignorant and subservient. Being well-spoken and a leader leaves such a strong impression on them, both Muslim and non-Muslim.

One leader's active role in her own job interview challenged patriarchal norms about women working outside of the home despite being married and mothering children. Jamilah noticed that students in her school could distinguish patriarchal, cultural influences on community decisions from religious influences rooted in fairness and justice. She supported this by promoting the open inquiry of religious teachings and community decisions, thereby confronting the norms of teaching children to blindly abide by all religious doctrines. Because many religious institutions are led by men, these women's presence and care to demonstrate excellence in their leadership work challenges the misdirected patriarchy that burdens many Islamic school leaders.

Even within American Islamic schools, patriarchal forces dictate the community's response to women as school leaders. These women choose to lead through an ethics of care to model excellence in an effort to demonstrate their successful leadership practices. Khadijah A. reflected 
that she serves a role model for those students in her school who do not have many images of strong Muslim women as leaders.

So I think that they look at me as a role model, all the way around. But I think that they still think of me as that cool role model, that I can still rollerblade and I can still be a [Muslim woman]. And I can still do this, and yet, still be in the, you know, Islam and stuff.

S.P.'s leadership decisions were challenged so consistently that she would proclaim her own self-affirmations: "I am the leader. I have to be calm. I have to be in charge...but I have to be confident at what I do, and I have to deal with things quickly." When she felt that others were questioning her judgments, she reminded them of her leadership qualifications: "I could make a good school. I could make a difference. I could make a better plan." Even Hawa felt that other board members only acknowledged her reluctance to support a decision when she spoke passionately about their obligation to adhere to Islamic principles of leadership. These women shared numerous stories of gender-based biases rooted in patriarchal forms of oppression. But in each situation, they responded through an ethics of care, advocating for the sustainability and strength of their schools over their own personal sense of affirmation and support.

Caring as other-mothering. These women leaders demonstrated caring in their nurturing of students and staff members, often in an attempt to address injustices or inequities experienced or to provide emotional support during challenging times. Sumayyah shared the importance of leading through caring when she reflected: "We try to be more sweet and nurturing than tough and hard lined." S.P. stated this role succinctly: "[I serve as] "mother [and] grandmother." She illustrated her ethics of care as a form of emotional support by describing the importance of greeting the arriving students, many of whom may have been rushed and feeling uncared for.

I don't like to see people hurt, and I think it's kind of the mother [in me]. And, like I said earlier, when I'm standing at the front door, really the kids that are coming in are like mine. They're my children. I mean I get hugs. I get, you know. I can influence whether they are happy or sad. I can burst their bubble or not. And it just gives me a good feeling. I like interactions like that. I like being cared for, like I hope people want to be cared for. And I think that's the woman inside of me. I don't see that so much in men. 
Sakina described her expressions of care as an attempt to nurture others and necessary to supporting students' academic achievement when they need redirection in the classroom.

And, we are all women, and we are very nurturing. We have to be nurturing, and if you just show a little compassion, a little this, a little you know, and they go and sit down back in the class again, you know.

Hafsa also described nurturing as a practice of supporting someone emotionally: "I'm usually [trying] to be a nurturer, and when someone has a problem, if a student comes with a complaint or something, [I] try to just nurture him and calm him down." Samantha extended an ethics of care to female staff who need emotional support in an attempt to transform their capacity to meet their students' needs: "You know we hug each other, 'how are you,' 'hi,' 'how are you doing,' 'you look like you're having a bad day, I'll give you a hug.' It makes a difference. A hug makes a big difference."

The leaders demonstrated a sense of caring through nurturing as an attempt to change one's emotional status or establish equitable feelings among students and staff.

Beyond caring to communicate emotional support, some of the leaders mothered in order to create administrative changes. Jamilah found herself mothering the women on her staff by demonstrating care through compassionate responses to their work schedule requests. She recalled a situation in which she needed to create an alternative work schedule to address a staff member's family schedule that she felt would increase this person's work performance and longterm satisfaction.

Like, when I do schedules, I know this woman has 5 kids, [that] she's going to drive 45 minutes to get home, [and so] I'm not going to overburden her schedule. If she says, "I really can't come in one day a week," I'm going to fit her schedule in four days so she can get that day off and take a break.

In this example, Jamilah utilizes her ethic of care to create an equitable work schedule for a staff member. Hafsa recalled instructing the teachers to change their classroom disciplinary processes by showing the links between caring and their knowledge of child development. 
You need to go back there and really think from the child's perspective also. For example, if you're making a child sit there all day, and if there are times that they [the teachers] are meeting and the teacher says, "Oh, it's been too long," think about your students! ...I'm too big on "from a child's perspective," and the compassion really comes down to their level. And I think of that as because I'm a woman.

Hafsa showed her sense of care as an attempt to change how teachers understood the impact of their discipline procedures on their students. Sakina guided a new teacher to use caring more effectively in classroom instruction. He responded positively by telling her, "You are like, you're like a mother to all of us." The roles of mother and other-mother were expressions of leadership work that demonstrated feminine authority to work as nurturing, caring leaders to bring meaningful change within the school community.

Caring as an Islamic obligation. These women leaders shared that their roles as nurturer, mother, and other-mother are not motivated by kindness or compassion, but rather are rooted in their conviction to embody the highest ideals of their faith. Summayah captured this clearly when she explained her motivations to care: "Because we should. That's the Prophet's way. We should love what we do, and we should [love] our deen [way of life], and we should care about our children." Hawa recalled an oft-told story of Umar ibn al-Khattab, who exemplified leadership through caring as a reminder that Muslims are obliged to meet the needs of all community members, even those of the most marginalized ones. Recognizing that it is a show of strength to maintain a nurturing environment in the midst of a demanding school context, Sakina said that she does this because "the children are an amāna [a trust]." Hafsa shared that nurturing is a trait exemplified through the Prophet's customs and that Islamic school leaders are obliged to emulate his manners: "I really learned from teaching the Prophet's way and leading and discipline with passion and compassion, that's what. And [during] a lot of our meetings we did discuss about compassionate discipline."

Caring as an Islamic obligation also extends to building a school climate that prioritizes the pursuit of social justice and mutual empowerment. Shanti described centering her leadership work on an Islamic model: "And I always told them, this was the [way of] Prophet Muhammad, peace be upon him....and I have created that culture where everybody feels empowered."

Choosing to lead in the Prophet's manner, with an emphasis on caring and nurturing, is an act of resistance. In an era of hyperfocus on school accountability, measurements of student achievement, and community pressures to out-perform local public schools, leading through caring both challenges norms of leading 
without emotion and seeks to construct nurturing school contexts based on Islamic traditions. Hafsa reflected this contradiction: "Yes, it is a business that we should be very professional, but at the same time we need to have that human touch, dealing with kids...you need to be a mother to understand these kids."

Women school leaders describe their roles and leadership work in a framework that is consistent with a critical ethics of care framework. They express their caring to establish equity within the school by challenging the injustices they see within it and confronting oppression in multiple forms through their leadership work. And being recognized as mothers and other-mothers in their leadership capacity emphasizes the importance of nurturing as an expression of a critical ethics of care. Moreover, each of them communicated that their caring work is motivated by the Islamic obligation to model the Prophet's practices. The work described by these women is a Muslim expression of an ethics of care framework, as discussed in the final section.

\section{Discussion}

These women school leaders embody the characteristics of leaders utilizing a critical ethics of care framework. Their responsibilities extend beyond mere administration, for they are making deliberate attempts to establish equitable teaching and learning practices in small community schools. Given the numerous instances of anti-Muslim sentiment across the country, the leadership needed to both sustain and grow an Islamic school in this country and at this time are examples of strength and resilience. This article considers how a critical ethics of care framework can help make meaning out of their values, behaviors, and practices.

A critical ethics of care framework is rooted in social justice advocacy and displayed by choosing to lead in ways designed to establish equity in the presence of injustice. Anchored by the principles of feminist research, the study of a critical ethics of care includes the analysis of participants' narrations of their own experiences of caring while leading. Although simply leading by caring offers an opportunity to show emotions, a critical ethics of care uses the act of caring to transform the realities and lived experiences of others to advance social justice and equity. A critical ethics of care demonstrates strength against the status quo in order to enact meaningful change that influences the complex lives of others.

The participants described leadership roles and responsibilities consistent with leading through a critical ethics of care framework, shared examples of caring as an effort to construct equitable school practices, and prioritized replacing inequities with equity despite the limited available resources or stakeholder pressure. These women resisted oppression while caring how the larger society perceived their school. Their mere presence and commitment to 
community-based social justice work showed that they cared about their school's reputation in a social context. And, each one shared stories of mothering and other-mothering through her leadership practices to evoke caring as a form of nurturing. This sentiment was not simply to be kind to others, but to mother change in another's emotional state, mothering change through operationalizing change in the school, and mothering as a form of nurturing change throughout the experience.

The leadership experiences related above advance a Muslim-centered conceptualization of a critical feminist ethics of care. Consistent with the foundational principles of a Black feminist critical ethics of care, Muslim women are mobilized by a shared priority to establish equitable teaching and learning experiences within their children's schools. This motivation is rooted in the recognition that pervasive anti-Muslim sentiment negatively impacts the community and that their leadership work can be utilized to challenge and confront the ensuing injustices. From the establishment of American Islamic schools as cultural institutions that uplift their students' faith identities to the innovative work of developing leadership practices that prioritize social justice work, a Muslim feminist ethics of care framework helps make meaning of the work needed to bring about equity within these schools.

Future scholarship can continue to explore the core components of a Muslim ethics of care framework and its conceptual associations with other critical ethics of care. As a scholar of the teaching, learning, and leadership practices that impact American Muslim students, I am interested in developing these concepts further to ensure that they effectively describe the work necessary to establish equity for this faith-marginalized community. And, as education research continues to include diverse expressions of school leadership, I hope that this will contribute to a comprehensive global description of leadership. A critical ethics of care leadership framework is grounded in transforming a community, and the women of this study who helped construct a conceptualization of a Muslim ethics of care are trailblazers for their work, their faith-based motivations, and their contribution to new knowledge in the field of education leadership. They continue to shape equity through social justice work for marginalized students within their school communities. 


\section{References}

Bass, L. (2012). When care trumps justice: The operationalization of black feminist caring in educational leadership. International Journal of Qualitative Studies in Education, 25(1), 73-87. doi:10.1080/09518398.2011.647721

Beauboeuf-Lafontant, T. (2005). Womanist lessons for reinventing teaching. Journal of Teacher Education, 56(5), 436-445 doi: $10.1177 / 0022487105282576$

Brown, M. E., Treviño, L. K., \& Harrison, D. A. (2005). Ethical leadership: A social learning perspective for construct development and testing. Organizational Behavior and Human Decision Processes, 97, 117-134.

Capper, C. A. (2015). The 20th-year anniversary of critical race theory in education: Implications for leading to eliminate racism. Educational Administration Quarterly, 51(5), 791-833.

Cherkowski, S., Walker, K. D., \& Kutsyuruba, B. (2015). Principals' moral agency and ethical decision-making: Toward a transformational ethics. International Journal of Education Policy \& Leadership, 10(5), 1-17.

Comber, B., \& Kamler, B. (2009). Sustaining the next generation of teacherresearchers to work for social justice (Doctoral dissertation, SAGE).

Dantley, M. E., \& Tillman, L. C. (2006). Social justice and moral transformative leadership. Leadership for social justice: Making revolutions in education, 16-30.

DeCuir, A. (2016). Roles \& responsibilities of the women leading American Islamic schools. International Journal of Educational Leadership Preparation, 11(1).

Dufresne, P., \& McKenzie, A. S. (2009). A culture of ethical leadership. Principal Leadership, 10(2), 36-39.

Esposito, J. (2011). What everyone needs to know about Islam. New York, NY: Oxford University Press. 
Furman, G. (2012). Social justice leadership as praxis. Educational Administration Quarterly, 48, 191-229.

Gardiner, M. E., \& Tenuto, P. L. (2015). Reflections of practicing school principals on ethical leadership and decision-making: Confronting social injustice. Principal's Research Review, 10(6), 1-8.

Gilligan, C. 1982. In a different voice: Psychological theory and women's development, Cambridge, MA: Harvard University Press.

Khalifa, M. A., Khalil, D., Marsh, T. E., \& Halloran, C. (2018). Toward an Indigenous, Decolonizing School Leadership: A Literature Review. Educational Administration Quarterly, 0013161X18809348

Khalil, D., \& DeCuir, A. (2018). This is us: Islamic feminist school leadership. Journal of Educational Administration and History, 50(2), 94-112.

Klenowski, V., \& Ehrich, L. C. (2016). Transitioning towards ethical leadership: A collaborative investigation of achieving equity in times of high-stakes accountability. International Studies in Educational Administration (Commonwealth Council for Educational Administration \& Management (CCEAM)), 44(1), 41-54.

Memon, N. (2017). Islamic education in the United States. In Handbook of Islamic Education. Cham: Springer International Publishing, 1-14.

Mitra, D. 2004. The significance of students: Can increasing student voice in schools lead to gains in youth development? Teachers College Record, 106(4): 651-688.

Murtadha, K., \& Watts, D. M. (2005). Linking the struggle for education and social justice: Historical perspectives of African American leadership in schools. Educational Administration Quarterly, 41(4), 591-608.

Noddings, N. (2006). Educational leaders as caring teachers. School Leadership \& Management, 26(4), 339-345.

Rashid, H., \& Muhammad, Z. (1992). The Sister Clara Muhammad schools: Pioneers in the development of Islamic education in America. Journal of Negro Education, 61(2), 178-185. 
Robinson, D., \& Mazid, I. (2016). Embracing family diversity through transformative educational leadership, the ethics of care, and community uplift in schools. Journal of School Public Relations, 37(2), 203-226.

Smith, D. (2014). Fostering collective ethical capacity within the teaching profession. Journal of Academic Ethics, 12(4), 271-286. doi:10.1007/s10805-014-9218-y

Smylie, M. A., Murphy, J., \& Louis, K. S. (2016). Caring school leadership: A multi- disciplinary, cross-occupational model. American Journal of Education, 123(1), 1-35. doi:10.1086/688166

Sosa-Provencio, M. (2016). Seeking a Mexicana/Mestiza critical feminist ethic of care: Diana's revolución of body and being. Journal of Latinos \& Education, 15(4), 303-319. doi:10.1080/15348431.2015.1134537

Starratt, R. J. (1996). Transforming educational administration: Meaning, community, and excellence. New York, NY: McGraw-Hill.

Starratt, R. J. (2004). Ethical leadership. San Francisco, CA: 1st Jossey-Bass.

Starratt, R. J. (2014). Ethics and social justice: Strangers passing in the night? In International handbook of educational leadership and social (in) justice (pp. 67-80). Springer, Dordrecht.

Tenuto, P. L., \& Gardiner, M. E. (2018). Interactive dimensions for leadership: An integrative literature review and model to promote ethical leadership praxis in a global society. International Journal of Leadership in Education, 21(5), 593-607. doi:10.1080/13603124.2017.1321783 